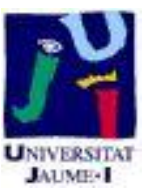

Título artículo / Títol article: LCA to evaluate the environmental impact for chemical pre-treatment in plastics metallization

Autores / Autors

Rosario Vidal, Jaume-Adrià Alberola-Borràs, Julio Gómez-Cordón, Enrique Moliner, Amaya Ortega, Eva Verdejo

Revista:

Journal of Polymers and the Environment

Versión / Versió:

Versió post-print

Cita bibliográfica / Cita bibliogràfica (ISO 690):

url Repositori UJI:
VIDAL, Rosario, et al. LCA to Evaluate the Environmental Impact for Chemical Pre-treatment in Plastics Metallization. Journal of Polymers and the Environment, (oct. 2016), p. 1-12

http://hdl.handle.net/10234/165114 


\section{LCA to evaluate the environmental impact for chemical pre-treatment in plastics metallization}

Rosario Vidal ${ }^{a}, *$, Jaume-Adrià Alberola-Borràs ${ }^{a}$, Julio Gómez-Cordón ${ }^{b}$, Enrique Moliner ${ }^{c}$, Amaya Ortega $^{c}$, Eva Verdejo ${ }^{c}$

${ }^{a}$ Dept. of Mechanical Engineering and Construction, GID, Universitat Jaume I, Av. Sos Baynat s/n, 12071 Castellón, Spain

${ }^{b}$ Avanzare Innovación Tecnológica, Avda Lentiscares 4-6, E-26370, Navarrete, Spain

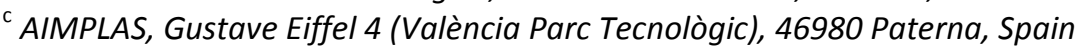

*Corresponding author. E-mail: vidal@uji.es. Tel: +34 964729252

\section{Abstract}

The life cycle assessment (LCA) methodology was used to calculate the environmental impacts of the current chemical pre-treatment with chromium (VI) for electroplating acrylonitrile butadiene styrene (ABS). The inventory comprised: the procurement of chemicals; the manufacturing process with successive baths and rinses that requires, in addition to chemicals, energy to heat baths, air agitation, filtration, and so forth, wastewater treatment and air emissions; and also the treatment of sludges from wastewater treatment and exhausted baths. Chromic acid was almost the unique responsible of eco-toxicity (97.5\%) and human toxicity-cancer (99.8\%) and it was one of the highest contributor to climate change, cumulative energy demand, fossil fuel depletion, human toxicity non-cancer, and in abiotic depletion.

\section{Keywords}

Life Cycle Assessment (LCA), Chromic Acid, Plastic Metallization, Plating, Etching 


\section{Introduction}

Plating of plastic materials has evolved into a big business, covering huge amount of commercial applications. Plastic products are plated for electrically conductive layers in electrical engineering (e.g., printed circuit boards), for electromagnetic interference shielding and for decorative and protective layers (e.g., automobile trims, bathroom components, perfume bottle caps).

The basic problem in attempting to electroplate onto plastic substrates is that they are electrical isolators and cannot be immersed in a plating solution and coated in the way that metal objects can. To solve this drawback, a good-adhesion conductive film must be applied onto the plastic surface for achieving a good performance in the plating process.

The most common method for plating plastic is electroplating. In order to activate the surface of the plastic and successfully plating, it is necessary to employ etching solutions based on carcinogenic chromic acid and toxic Pd/Sn colloids. However, these methodologies are subject to restrictions and disadvantages due to environmental contamination and health and safetyrelated issues.

In an attempt to avoid the use of carcinogenic hexavalent chromic acid in pre-treatments for metalizing plastic surfaces, which will be banned in 2017 by REACH regulations [1], the plastic plating industry is thoroughly investigating new technologies to find alternatives to the use of traditional plating practices. Some of these most known alternative technologies are physical vapour deposition (PVD), chemical vapour deposition (CVD) and thermal spraying. Olivera et al. [2] have reviewed the literature about eco-friendly methods of plating ABS. 
The evaluation of the environmental benefits of potential alternatives may be accomplished using the Life Cycle Assessment (LCA) methodology. A previous study done by Harscoet [3] highlighted the environmental impacts during the production of chromic acid and the chromic acid anodising. Few studies have been performed to analyse the impact of substitutes for chromic acid anodising: Serres et al. [4] and García et al. [5] have assessed the substitution of hard chromium with thermal spray and laser techniques; Benveniste et al. [6] compared energy requirements and some environmental burdens for ceramics Physical Vapour Deposition, $\mathrm{SiO}_{\mathrm{x}}$ Plasma and Chromium electroplating; and Jugy et al. [7] compared electrochemical process for the anodising treatment of aluminium against corrosion with and without chromic acid.

Also few studies, and furthermore preliminary, have been published to analyse the impacts in order to activate the surface of the plastics:, Garraín et al. [8, 9] compared conductive coating painting, electroless plating, and high-vacuum metal deposition; Bayus et al. [10] estimated the energy requirements to vaporize aluminium on plastic foil; and Espinosa et al. [11] analysed the cumulative energy demand of polymer solar cells including an electrode of aluminium and chromium deposited by a roll-to-roll sputtering procedure onto a plastic foil substrate

The aim of this work is to provide an environmental assessment baseline applied to the chemical pre-treatment of metallization of polymers with chromium acid. This baseline can be used as a reference to compare with other processes in the future.

The Life Cycle Assessment methodology was used to assess the environmental impacts associated with the consumption of energy, materials and the process emissions from the extraction and processing of materials, manufacturing and wastes disposal by applying different impact assessment methods: USETOX, IPCC, CED and CML, which are incorporated within the $\operatorname{SimaPro}^{\circledR}$ software. 


\section{Materials and methods}

The LCA methodology was used in this study to calculate the environmental impacts of the chemical etching of acrylonitrile butadiene styrene (ABS) during its entire life cycle. A simplified LCA was applied in order to obtain a more suitable study. LCA was applied according to the guidelines provided by ISO 14040:2006 [12] and ISO 14044:2006 [13]. The LCA software application SimaPro ${ }^{\circledR}$ was used to tackle the development of the study more effectively.

Field data for the study was obtained from two manufacturing company suppliers from the automotive and sanitary sectors: one company from Spain, with an annual production of ABS electroplating of $40,000 \mathrm{~m}^{2}$ (manufacturing process A); and another company from Turkey, with an annual production of ABS electroplating of $150,000 \mathrm{~m}^{2}$ (manufacturing process B).

Nowadays, most of plastic metallization processes (about $85 \%$ ) are made with acrylonitrile butadiene styrene (ABS) as substrate. The reason is that ABS shows higher adhesion levels of the metallic films to the substrate with only a chemical pre-treatment instead of mechanical abrasion pre-treatment [14].

Data about chemical etching was considered, comprising: pre-etching and etching, neutralization, activation, acceleration and electroless nickel. In those cases where no field data were available, data were gathered from LCA databases and from scientific literature.

\subsection{Life cycle assessment}

LCA is a methodology to evaluate the environmental burdens associated with a product, process or activity by identifying and quantifying energy, materials used, and wastes released to the environment; to assess the impact thereof, identify, and evaluate opportunities to affect environmental improvements. The assessment includes the entire life cycle of the product, process or activity, which encompasses: extracting and processing raw materials; 
manufacturing, transportation, and distribution; use, re-use, and maintenance; recycling and final disposal.

According to ISO standards, LCA consists of four phases: goal and scope definition, inventory analysis, impact assessment, and interpretation [13]. The goal and scope definition determines the guidelines to be followed during the rest of the study by specifying the reason for conducting the study, intended use of the results, intended audience, system boundaries, functional unit, data requirements and study limitations. The inventory analysis involves collecting data to create a $\mathrm{LCl}$ of the inputs (energy and materials) and outputs (environmental releases and waste) associated with each stage of the life cycle. The impact assessment translates the $\mathrm{LCl}$ data into potential environmental impacts. To this end, the impact categories under study must be defined (categorization), the inventory data must be assigned to specific impact categories (classification), and the level of impact must be evaluated according to predefined assessment methods (characterization). Impact assessment may also include other additional steps (normalization, grouping and weighting) to facilitate the interpretation phase, but these are not mandatory according to ISO standards. Finally, the interpretation phase combines and summarizes the results from the inventory analysis and the impact assessment (consistent with the defined goal and scope) in order to reach conclusions and recommendations.

\subsection{Goal and scope definition}

The aim of this work was to provide the environmental impacts of the chemical pre-treatment, prior to electroplating polymer surfaces.

\subsubsection{System description and boundaries}

This paper was focused on these unitary process of the pre-treatment process (Fig. 1): 
- In etching, small micro and nanoporosities are achieved in the plastic surface enabling subsequent metal coating. Historically, several formulations of chromic/sulphuric acid mixtures have been used to pre-treat ABS surfaces prior to activation [14].

- Neutralization is necessary to remove traces of hexavalent chromium from etching.

- Activation is a pre-coating step process. In general, catalysts (activators) are mixtures of strong acids with palladium particles $\left(\mathrm{Pd}^{0}\right)$ surrounded of $\mathrm{Sn}(\mathrm{IV})$ species [15-17].

- Acceleration is used to remove excess tin. Diluted acid or alkaline solutions are used.

- Electroless deposition consists of preferably nickel, although copper is also used, necessary for subsequent electroplating.

In addition, the end of life of wastes and wastewater of this chemical pre-treatment were included.

In the pre-treatment, degreasing and cleaning are optional processes which are not included in our system. Once finished the pre-treatment, and out of our boundaries, the metallization process begins with a bright acid copper bath, followed by three different electroplating options. On the first option, bright nickel is applied to the surface, followed by chrome. The second option consists of the application of double nickel, nickel microporous, and chrome. On the third option, double nickel and micro-cracked chrome are applied to the surface.

The life cycle of the chemical pre-treatment of electroplating was divided in these three major stages or sub-systems:

- Materials: chemicals for the pre-treatment of the polymer before electroplating.

- Manufacturing: the pieces go through successive baths and rinses. Energy is required for heating baths, air agitation, filtration, etc. If wastewater is treated in situ, then it is included in manufacturing. In addition, air emissions are included. 
- Wastes: sludges of wastewater treatment, exhausted baths and wastewater treatment (if exterior to the manufacturing enterprise), together with other hazardous and nonhazardous wastes, are properly treated and removed.

An LCA-based tool was developed to calculate the environmental impacts, according to List of Tables

Table 1. List of inputs to treat $1 \mathrm{~m}^{2}$ of $A B S$

Table 2. Impact assessment for $1 \mathrm{~m}^{2}$ of surface treated

Table 3. Estimated air emissions

Table 4. Sensitivity analysis 
- This tool performed different calculations, such as: amount of drag-out, rinse water, discharged water, evaporation losses, composition of discharged water, composition of exhausted water, composition of each sludge fraction, distribution of electricity, demand in thermal energy, lighting, filtration, agitation, etc.

The results of this tool were, first of all, data to complete the life cycle inventory: amounts of electricity per use, air emissions, reagents for waste water treatment, sewage, composition of sludges and emissions from the removal of all wastes. Secondly, with the use of indicators obtained from SimaPro ${ }^{\circledR}$, results were the environmental impacts.

\subsubsection{Functional unit}

Functional unit was $1 \mathrm{~m}^{2}$ of chemical pre-treatment for the metallization of thermoplastic pieces with a performance like ABS.

\subsection{Life cycle inventory}

\subsubsection{Chemicals for baths processing}

The two manufacturing companies provided the list of chemicals, water and energy of List of Tables

Table 1. List of inputs to treat $1 \mathrm{~m}^{2}$ of $A B S$

Table 2. Impact assessment for $1 \mathrm{~m}^{2}$ of surface treated

Table 3. Estimated air emissions

Table 4. Sensitivity analysis 
. In this table, the suffixes $A, B$ and $C$ refer to its use in process manufacturing $A$, process manufacturing $B$ or if it is common for the two manufacturing processes. In the column 'Comments', a brief indication of the production route from Ecoinvent ${ }^{\circledR} \vee 3.0$ inventory is included [18-22]. Some chemicals are commercial dissolutions (Udique ${ }^{\circledR}$ and Atotech ${ }^{\circledR}$ ), from which individual concentrations are estimated from average values of the MSDS (Material Safety Data Sheet).

LCl data for chromium anhydride were obtained from Harscoet and Froelich [3], and Kowalski et al. [23]. Chromium trioxide can be produced by mixing sodium dichromate with sulphuric acid in a reactor heated externally and stirred with a sweep agitator. Water, chromium trioxide and sodium bisulphate are finally separated and the chromic acid layer is tapped from the reactor and flaked on water-cooled rolls to produce the commercial product. The amounts of sulphuric acid and sodium dichromate were calculated stoichiometrically and their LCl were adopted from Ecoinvent ${ }^{\circledR} \mathrm{v}$ 3.0.

\subsubsection{Rinses}

After each bath, the jig is dipped in two or three counter flow rinses (as in Fig. 2 where a triple counter flow is represented). Drag-out rinse water, containing process chemicals, has to be treated prior to be discharged to sewage.

To reduce the drag-out, a mist suppressant is added in the etching bath as wetting agent. The addition of polyfluorinated surfactants (PFOS and alternatives) to the chromic acid bath goes down the surface tension by forming a thin foamy layer on the surface of the chrome bath. That mist suppressant layer reduces the formation of $\mathrm{Cr}(\mathrm{VI})$ aerosols.

PFOS and derivatives are, however, an environmental and health problem, as these substances are being biomagnified through the food chain. PFOS has many adverse effects, among others, 
it is an endocrine disrupting substance that affects the human fertility. From June 2008, the use of PFOS as mist suppressant in decorative chrome plating became illegal in the EU [24].

The drag-out of process solution and drag-in of rinse water lead to a continuous dilution and drop-off chemical concentration, without a recovery of the drag-out, the final bath concentration is:

$$
C_{o n}=\left[\frac{V-D}{V}\right]^{n} \cdot C_{o}
$$

where,

$C_{o}$ : Concentration of chemicals in bath solution

$C_{o n}$ : Concentration of chemicals in bath solution after $(n)$ workloads are processed

$D$ : Volume of drag-out in each workload processed

$n$ : Number of workloads processed

$V$ : Bath volume

For each bath, literature values were adopted for rinse criterion $(R)$, drag-out $(D)$ and evaporation losses $(E)[25,26]$.

The volume $(W)$ of rinse water to achieve a rinse criterion $(R)$ at a given drag-out $(D)$ is estimated as:

$$
W=D \cdot \sqrt[i]{R}
$$

The exhausted baths are treated by authorised agents. The concentration (including drag-out recovery) is:

$$
C_{\text {on }}=\left[\frac{V-D \cdot\left(1-\frac{W_{R}}{W} \cdot S\right)}{V}\right]^{n} \cdot C_{o}
$$

Where $W_{R}$ is the quantity of rinse water to replace drag-out $(D)$ and evaporation losses $(E)$. 
The concentration of the discharged water is estimated by mass balance considering the initial value $\left(C_{o}\right)$ and the estimated final concentration $\left(C_{o n}\right)$.

\subsubsection{Energy demand}

The two manufacturing companies provided the consumption of energy and additional information such as number and size of tanks, frequency of filled/emptied cycles, refills, operating temperatures, etc.

Energy is required for heating baths, air agitation and water filtration in acceleration tank; lighting; and other uses, such as crane, air aspiration, ventilation, reagent pumping, filter press, etc.

Etching tank and acceleration tank are heated to maintain the desired temperature $\left(70^{\circ} \mathrm{C}\right.$ and $40-50{ }^{\circ} \mathrm{C}$, respectively). For each tank, conductive, radiation, and convective losses were calculated from the characteristics of the tanks like dimensions of vertical walls, wall thickness, dimensions of the bottom, and difference of temperatures with the local environment [27].

Thermal energy also comprises energy losses, tank heating after weekend break and heating tank loads and refills.

\subsubsection{Air emissions}

The air emissions were theoretically estimated from evaporation and volatilization calculations. Evaporation losses were estimated with the evaporation rate from IHOBE [28] as a function of bath temperature and aspiration velocity, except in etching bath, since a mist suppressant is added with an efficiency rate of $99.5 \%$ [29]. In each manufacturing company, a different mist suppressant is added: Fumetrol 21 LF2 (a non-PFOS mist suppressant chemical alternative) and Fumetrol 140 TR (PFOS). In all process tanks, water evaporated has to be replaced. 
Volatilization losses were obtained from EPA's Chemical Engineering Branch Manual [30], based on Henry's law constant as defined by Sander [31].

\subsubsection{Wastewater treatment}

Chemical treatment of chromium wastewater is supposed to be conducted in two steps in the wastewater treatment plant. In the first step, hexavalent chromium is reduced to trivalent chromium by using a chemical reducing agent. The trivalent chromium is precipitated during the second stage of treatment.

The reducing agent used is sodium bisulphite $\left(\mathrm{NaHSO}_{3}\right)$. The sulphite anion is the responsible for reducing hexavalent chromium. During the reduction treatment, a fraction of $\mathrm{Cr}$ (VI) remains at a rate of $0.18 \mathrm{~g}$ per $1 \mathrm{~kg}$ of $\mathrm{CrO}_{3}$ treated $[3,23]$ and it is considered as a water emission.

Reduction reaction is strongly $\mathrm{pH}$-dependent. Chromium reduction processes are generally conducted at $\mathrm{pH}$ values of 2 to 4 with the addition of sulphuric acid [32].

The precipitation of metals is carried out by adjusting the $\mathrm{pH}$ to the optimum value of precipitation of each metal in the form of hydroxide by adding $\mathrm{NaOH}$. The amount of $\mathrm{NaOH}$ was calculated stoichiometrically. Although flocculants are added in practice, they were not considered in the calculation. Metal hydroxides are decanted and filtered through filterpresses.

Afterwards chromium treatment, the water is discharged as sewage, which treatment is modelled with Ecoinvent in a medium sized municipal wastewater treatment plant (capacity class 3). 


\subsubsection{Sludges}

Sludges of wastewater treatment from etching, catalyst and electroless nickel baths are codified as hazardous wastes (LER 110109*). Sludges from wastewater treatment of the neutralisation and acceleration baths are codified as non-hazardous wastes (LER 110110).

Exhausted etching baths processes are codified as acid baths (LER $110105^{*}$ ) and the rest of the exhausted baths are treated by authorised agents. The treatment of these wastewaters was estimated and the amounts of sodium bisulphite and $\mathrm{NaOH}$ were calculated.

Non-hazardous sludges of wastewater treatment are assumed to be directly landfilled in residual landfills. Hazardous sludges are solidified with cement. The water content in all sludges was fixed in $30 \%$. Elemental waste composition was first determined for each sludge fraction based on the composition of the reaction products of reduction and neutralizationprecipitation. Secondly, elemental waste compositions were used as inputs to the model of Doka [33] in order to calculate the specific burdens from waste treatment. These burdens were introduced in SimaPro ${ }^{\circledR}$ to model LCA.

\subsubsection{Other wastes}

Mainly packaging materials compose industrial waste equivalent to municipal solid waste. Packaging was not included as raw material, so their wastes were not included.

The containers contaminated with chemicals (LER 150110*) and contaminated absorbent materials, such as filters (LER 150202*) are also hazardous wastes and they were included in the inventory. 


\subsection{Impact assessment}

ISO developed a standard for conducting an impact assessment entitled ISO 14040, Life Cycle Impact Assessment [12], which states that the first three steps - impact category selection, classification, and characterization - are mandatory steps for an LCA.

The first step in an LCA is to select the impact categories that will be considered as part of the overall LCA. This selection is based considering the goals of this assessment.

New technologies are focused on plastic plating free of Chromium VI, a toxic substance whose use is restricted by the European Restriction of Hazardous Substances Directive. For this reason, toxicity was one of the most significant impact categories to be assessed. USEtox model [34] is, according with Hauschild et al. [35], Pizzol et al. [36], etc., the best among existing characterization models for toxicity. The three impact categories of USEtox model were used: human toxicity, cancer effects (HTCP); human toxicity, non-cancer effects (HTNCP) and eco-toxicity (ETP).

Traditional plastic plating industries are intensive consumers of metals like Chromium, Palladium/Stannum, Nickel, etc., and fossil fuels, too. The model CML 2002 [37] is one of the best among existing characterization models for scarcity [35]. To show the consumption of mineral resources and energy, the environmental impact of abiotic depletion potential was divided into mineral resources depletion potential (ADP) and fossil energy depletion potential (ADPF).

The amount of energy required is another important indicator. The cumulative energy demand (CED) $\vee 1.08$ was also selected in order to ease energy comparisons. CED assessment was based on the method published by Ecoinvent ${ }^{\circledR}$ [38] and expanded within the SimaPro ${ }^{\circledR}$ software application. 
Finally, the most important impact categories related to energy are also relevant. Global warming (GWP) is the most frequent impact category in life cycle assessments of energy. At midpoint level, Climate Change baseline model of 100 years of the IPCC is the reference model [39]. In addition to GWP, a certain number of studies estimate other impact categories. Acidification (AP) and eutrophication (EP) are included in $20-40 \%$ of the studies reviewed by Cherubini and Strømman [40]. This two impact categories were used according with CML method.

Calculations were performed with the software SimaPro ${ }^{\circledR}$ 8.0.3.14.

\section{Results and discussion}

\subsection{Impact categories contributions}

Total average results for each impact category from the two manufacturing processes are shown in Table 2. The two manufacturing processes presented significant differences in each impact category. The highest differences were produced in acidification, eutrophication and human toxicity-non cancer ( $52.5 \%, 48.5 \%$ and $38.6 \%$ respectively), as a consequence of the different compositions of baths with consequent different impacts in the chemicals production (Fig. 4) and in the wastewater treatment and disposal (Fig. 5).

In Fig. 3, average impacts are divided in raw materials, manufacturing and wastes. Impact on climate change was mostly produced by raw materials procurement and electricity consumption during manufacturing. Chromic oxide (used during the etching step) was the most contaminant in climate change impact as raw material (44-48 \% in Fig. 4). Other materials with significant impact on climate change were tin (II) chloride dihydrate, oxalic acid and citric acid (only used in process A), palladium chloride (only used in process B) and sodium hypophosphite, hydrochloric acid and nickel (II) sulphate used in both processes. 
Electricity was the main contributor to all impact categories during the manufacturing phase. It has to be noted that in the case of process $A$, the procurement of reagents for wastewater treatment in situ was included in the manufacturing phase, and its contribution was $17 \%$ in climate change. In process $B$, the contribution of all reagents used in wastewater treatment was included in wastes' treatment phase.

Since climate change was mainly produced because of the use of energy in each stage, a similar pattern followed the impact categories of cumulative energy demand and fossil fuels depletion.

Almost all the contribution to human toxicity-cancer by raw materials was due to chromic acid $(99.6 \%)$ (Fig. 4). During the waste stage the main contributor was also chrome that was present in sludge of exhausted acid baths (LER 110105*) and in sludge of wastewater treatment (LER 110109*) (Fig. 5). Eco-toxicity impact category followed a similar pattern (89\% in raw materials). The total removal of $\mathrm{CrO}_{3}$ would significantly decrease these impact categories: $99.8 \%$ and $97.5 \%$, respectively.

Palladium salts used in activation bath in process B had a significant effect in human toxicity non-cancer, impact category (39\% in raw material stage). Other significant raw materials in this impact category were chromic acid (40\% and $20 \%$ for A and B process respectively) and nickel salts (29\%).

Tin salts for activation baths were the main contributor to abiotic depletion impact category ( $55 \%$ and $49 \%$ in raw materials for process A and process B, respectively). Chromic acid was the second most important ( $38 \%$ and $32 \%$ ) and the third one was palladium salts in process B (11\%). 
Palladium salts in Company (B) had a significant contribution in acidification impact category (Fig. 4), followed by nickel salts in materials' stage. The contribution of chromic acid to acidification was not as important as in other impact categories.

Wastewater reagents and hazardous wastes LER 110109* and LER 110105*, both together with the presence of $\mathrm{Cr}(\mathrm{VI})$, were the most significant contributors for waste stage.

\subsection{Discussion}

The energy consumption during manufacturing (electricity and diesel) was $2.4-2.9 \mathrm{kWh} / \mathrm{m}^{2}$, relatively low compared with the electrodeposition processes, e.g. [26] reported values of 21.8 $\mathrm{kWh} / \mathrm{m}^{2}$ for the total process of electroplating plastics (including chemical etching); Benveniste et al. [6] reported $300 \mathrm{MJ} / \mathrm{m}^{2}$ of cumulative energy demand as average value of electroplating $\mathrm{Cr}(\mathrm{VI})$ in Europe and Espinosa et al. [11] estimated $388 \mathrm{MJ} / \mathrm{m}^{2}$ of CED without considering the PET substrate. Chemical pre-treatment in this study was about $12.5 \%$ and $9.7 \%$ of CED of the total electroplating process compared with values reported by [6] and [11], respectively.

Similarly, and compared with data reported by Benveniste et al. [6], carbon footprint of chemical pre-treatment (Table 2 ) was $18 \%$ of the average carbon footprint of the complete electrodeposition process (14.38 kg of $\left.\mathrm{CO}_{2} \mathrm{eq}\right)$.

The most important consumption of energy during manufacturing stage of chemical etching ( $71 \%$ in company $\mathrm{A}$ and $64 \%$ in company $\mathrm{B}$ ) was required to heat the baths, the rest was for lighting, crane movement, air agitation, filtration, pumping, etc. Reduction in bath temperatures (etching, acceleration and electroless nickel baths) would lead to an important saving of energy. This improvement is considered in the section Sensitivity analysis.

Chemical pre-treatment is an intensive water demanded process. The total amount of water depends on the rinses. In both manufacturing enterprises, water consumptions were $25-40$ 
$1 / \mathrm{m}^{2}$, respectively. This amount is the $10-15 \%$ of total consumption of the full electrodeposition process [26].

The significant impact in categories like eco-toxicity, human toxicity and eutrophication of wastewater treatment and disposal has to be noticed in these manufacturing processes. For this reason, wastewater would have to be included in comparative LCA.

Oppositely, atmospheric emissions during manufacturing were negligible. For example, [41] reported rates of $0.010 \mathrm{mg} / \mathrm{A} \cdot \mathrm{h}$ for electrodeposition baths of chrome with mist suppressors, considering a thickness of 0.1-0.3 $\mu \mathrm{m}$ [9]; the air emissions estimated of $\mathrm{Cr}(\mathrm{VI})$ were $2 \cdot 10^{-5}$ $7 \cdot 10^{-5} \mathrm{~g} / \mathrm{m}^{2}$. Results of Table 3 for $\mathrm{Cr}(\mathrm{VI})$ during chemical etching, estimated as explained in section 2.3.4, were three orders of magnitude lower.

This result is in good agreement with Kuo \& Wang [42], who underlined that it is the droplet creation following the bubble bursting that most contributes to the transfer of non-volatile compounds from liquid to air. It should however be noted that bubbles may either come from the bath sparging with air or from the water dissociation that takes place at the electrodes. In chemical pre-treatment, only the acceleration tank is sparged with air. Furthermore, aerosol generation is by far more significant when considering an electrolytic process than for a bath simply mixed by air sparging.

Wetting agents -Fumetrol 140 TR and Fumetrol 21 LF2-, at least with data that has been possible to analyse, do not exhibit significant impacts. Future researches will need to deepen their study of environmental impacts.

\subsection{Sensitivity analysis}

Two different scenarios were considered in Table 4 to analyse impact variations beyond those shown between the two production processes. The results of Table 2 were without transport. 
An average transport of $500 \mathrm{~km}$ by road of all chemicals would increase each environmental impact category almost negligibly.

The reduction of bath temperatures was more significant. A temperature reduction of $10^{\circ} \mathrm{C}$ in heated baths (maintaining the same amount of chemicals) reduced significantly these impact categories: CED (9.8\%), ADPF (9.1\%), GWP (7.9\%) and AP (7\%). Positive effects were also achieved with improvements in the insulation of the tanks. Other positive effect was continuous works without daily or weekly breaks.

\section{Conclusions}

The life cycle assessment (LCA) methodology was used in this study to calculate the environmental impacts of the current chemical pre-treatment with Chromium (VI) for electroplating ABS. Field data was obtained from two manufacturing companies.

The inventory comprised the procurement of chemicals; the manufacturing process with successive baths and rinses that requires in addition to chemicals, energy to heat baths, air agitation, filtration, etc., wastewater treatment and air emissions; and also the treatment of sludges from wastewater treatment and exhausted baths.

Environmental impacts of air emissions during manufacturing were negligible; this was not the case for environmental impacts of sludge with significant impacts in categories like ecotoxicity, human toxicity and eutrophication.

Chromic acid was almost the unique responsible of eco-toxicity (97.5\%) and human toxicitycancer (99.8\%). It was the main contributor during raw materials stage in climate change, cumulative energy demand and fossil fuel depletion and the second one in human toxicity noncancer, and in abiotic depletion. Therefore, the total removal of $\mathrm{CrO}_{3}$ would significantly decrease all these impact categories. 
In addition to the chromic acid, other reagents required special attention. The use of palladium salts originated a significant contribution in acidification impact category and human toxicity non-cancer; tin salts were the main contributor to abiotic depletion and nickel salts contributed to acidification and human toxicity non-cancer.

Sensitivity analysis showed a significant decrease of environmental impacts with bath temperature reduction. Finally, future researches will need to deepen environmental impacts of PFOS and alternatives.

\section{Acknowledgments}

Authors gratefully appreciate the financial support from Eco-innovation Initiative of the European Union for the project ECO/11/304394 "Cost effective industrialization of an ecofriendly pre-treatment for plastic chrome plating using self-assembly nanotechnology".

\section{References}

1. EC (2006) Regulation (EC) No 1907/2006 of the European Parliament and of the Council of 18 December 2006 concerning the Registration, Evaluation, Authorisation and Restriction of Chemicals (REACH), establishing a European Chemicals Agency, amending Directive 1999/4. European Union, Brussels, Belgium

2. Olivera S, Muralidhara HB, Venkatesh K, et al (2016) Plating on acrylonitrile-butadienestyrene (ABS) plastic: a review. J Mater Sci 51:3657-3674. doi: 10.1007/s10853-0159668-7

3. Harscoet E, Froelich D (2008) Use of LCA to evaluate the environmental benefits of substituting chromic acid anodizing (CAA). J Clean Prod 16:1294-1305. doi: 10.1016/j.jclepro.2007.06.010

4. Serres N, Hlawka F, Costil S, et al (2009) Dry coatings and ecodesign part. 1 - 
Environmental performances and chemical properties. Surf Coatings Technol 204:187196. doi: 10.1016/j.surfcoat.2009.07.012

5. Garcia-Alonso D, Serres N, Demian C, et al (2011) Pre-/During-/Post-Laser Processes to Enhance the Adhesion and Mechanical Properties of Thermal-Sprayed Coatings with a Reduced Environmental Impact. J Therm Spray Technol 20:719-735. doi: $10.1007 / \mathrm{s} 11666-011-9629-\mathrm{x}$

6. Benveniste G, Baldo GL, Perucca M, Ruggeri B (2007) LCA comparative analysis of different technologies for surface functionalism. 3rd Int Conf Life Cycle Manag 6.

7. Jugy C, Jacquemin L, Villemur C, et al (2016) Methodology for evaluating the sustainability of products and processes: application to alternative substitution techniques of chromium VI. Int J Interact Des Manuf 10:329-334. doi: 10.1007/s12008016-0324-5

8. Garraín D, Vidal R, Franco V, Martínez P (2008) Lca of Surface Coating Processes of Thermoplastics. 24-25.

9. Garraín D, Vidal R, Martínez P (2010) Análisis del Ciclo de Vida de los Procesos de Recubrimiento Metálico de Termoplásticos Life Cycle Assessment of Metallic Surface Coating Processes of Thermoplastics. Inf Tecnológica 21:59-64. doi: 10.1612/inf.tecnol.4118it.08

10. Bayus J, Ge C, Thorn B (2016) A preliminary environmental assessment of foil and metallized film centered laminates. Resour Conserv Recycl 115:31-41. doi: 10.1016/j.resconrec.2016.08.024

11. Espinosa N, García-Valverde R, Urbina A, et al (2012) Life cycle assessment of ITO-free flexible polymer solar cells prepared by roll-to-roll coating and printing. Sol Energy Mater Sol Cells 97:3-13. doi: 10.1016/j.solmat.2011.09.048

12. ISO E (2006) Environmental management. Life cycle assessment. Principles and framework (14040: 2006). 
13. ISO E (2006) Environmental management. Life cycle assessment. Requierements and guidelines (14044: 2006).

14. McCaskie JE (2006) Plating on plastics. Met Finish 104:31-39. doi: 10.1016/S00260576(06)80204-7

15. Cohen RL, West KW (1973) Generative and Stabilizing Processes in Tin-Palladium Sols and Palladium Sol Sensitizers. J Electrochem Soc 120:502. doi: 10.1149/1.2403486

16. Matijević E, Poskanzer AM, Zuman P (1975) The Characterization of the Stannous Chloride/ Palladium Chloride Catalysts for Electroless Plating. Plat Surf Finish 61:958965.

17. Cui X, Hutt DA, Scurr DJ, Conway PP (2011) The Evolution of Pd/Sn Catalytic Surfaces in Electroless Copper Deposition. J Electrochem Soc 158:D172. doi: 10.1149/1.3536543

18. Althaus H-J, Chudacoff M, Hischier R, et al (2007) Life cycle inventories of chemicals. Final Rep. ecoinvent data v2. 0 No 8:

19. Burger B, Bauer C (2007) Final report ecoinvent No. 6-XIII. Paul Scherrer Institut Villigen, Swiss Centre for Life Cycle Inventories: Dübendorf

20. Classen M, Althaus H-J, Blaser S, et al (2009) Life Cycle Inventories of Metals. Dübendorf, Switzerland

21. Frischknecht $\mathrm{R}$, Tuchschmid M, Faist Emmenegger $\mathrm{M}$, et al (2007) Strommix und stromnetz. Sachbilanzen von Energiesystemen. Final Rep. Ecoinvent v2. 0 No. 6Swiss Cent. Life Cycle Invent. Dübendorf, Villigen, Switz.

22. Jungbluth N (2007) Erdöl. Sachbilanzen von Energiesystemen: Grundlagen für den ökologischen Vergleich von Energiesystemen und den Einbezug von Energiesystemen in Ökobilanzen für die Schweiz. Ecoinvent report.

23. Kowalski Z, Kulczycka J, Wzorek Z (2007) Life cycle assessment of different variants of sodium chromate production in Poland. J Clean Prod 15:28-37. doi: 10.1016/j.jclepro.2005.05.026 
24. EC (2006) Directive 2006/122/EC of the European Parliament and of the Council of 12 December 2006 amending for the 30th time Council Directive 76/769/EEC on the approximation of the laws, regulations and administrative provisions of the Member States relating to re. Strasbourg

25. EC (2006) Reference document on best available techniques for the Surface treatment of plastic and metals using electrolytic or chemical process.

26. D E Medio Ambiente (2009) Guía de Mejores Técnicas Disponibles en España del Sector de Tratamiento de Superficies Metálicas y Plásticas 2009. MARM

27. IDAE (2007) Guía técnica para el diseño y cálculo del aislamiento térmico de conducciones, aparatos y equipos. Madrid

28. IHOBE (1997) Libro Blanco para la Minimización de Residuos y Emisiones. Recubrimientos electrolíticos. IHOBE

29. Poulsen PB, Gram LK, Jensen a. a., et al (2011) Substitution of PFOS for use in nondecorative hard chrome plating. Danish Environ. Prot. Agency

30. EPA (1991) Chemical Engineering branch manual for the preparation of engineering assessments. Cincinnati

31. Sander R (1999) Compilation of Henry's law Constants for Inorganic and Organic Species of Potential Importance in Environmental Chemistry.

32. Wang LK, Yung-Tse H, Nazih KS (2009) Handbook of Advanced Industrial and Hazardous Wastes Treatment. CRC Press Book

33. Doka G (2009) Life Cycle Inventories of Waste Treatment Services. Dübendorf

34. Rosenbaum R, Bachmann T, Gold L, et al (2008) USEtox-the UNEP-SETAC toxicity model: recommended characterisation factors for human toxicity and freshwater ecotoxicity in life cycle impact assessment. Int J Life Cycle Assess 13:532-546. doi: $10.1007 / \mathrm{s} 11367-008-0038-4$

35. Hauschild MZ, Goedkoop M, Guinée J, et al (2013) Identifying best existing practice for 
characterization modeling in life cycle impact assessment. Int J Life Cycle Assess 18:683-697. doi: 10.1007/s11367-012-0489-5

36. Pizzol M, Christensen P, Schmidt J, Thomsen M (2011) Impacts of "metals" on human health: a comparison between nine different methodologies for Life Cycle Impact Assessment (LCIA). J Clean Prod 19:646-656. doi: 10.1016/j.jclepro.2010.05.007

37. Guinee JB (2002) Handbook on life cycle assessment operational guide to the ISO standards. Int J Life Cycle Assess 7:311-313. doi: 10.1007/BF02978897

38. Frischknecht R, Jungbluth N, Althaus H-J, et al (2004) The ecoinvent Database: Overview and Methodological Framework (7 pp). Int J Life Cycle Assess 10:3-9. doi: 10.1065/Ica2004.10.181.1

39. Forster P, Ramaswamy V, Artaxo P, et al (2007) Changes in atmospheric constituents and in radiative forcing. 129-234.

40. Cherubini F, Strømman AH (2011) Life cycle assessment of bioenergy systems: state of the art and future challenges. Bioresour Technol 102:437-51. doi: 10.1016/j.biortech.2010.08.010

41. US EPA (1996) Emission Factor Documentation for AP-42 Section 12.20. United States Environmental Protection Agency

42. Kuo YM, Wang C Sen (2002) Effect of rise distance on droplets generated from bubble bursting on the surface of chromic acid solutions. Am Ind Hyg Assoc J 63:5-10. 
List of figures

Fig. 1. System description. System boundaries analysed are marked with dash line

Fig. 2. Recovery of drag-out with triple counter flow rinse

Fig. 3. Contribution of raw materials, manufacturing and wastes to total impacts

Fig. 4. Raw materials impacts

Fig. 5. Waste impacts (impacts of reagents procurement are not included) 


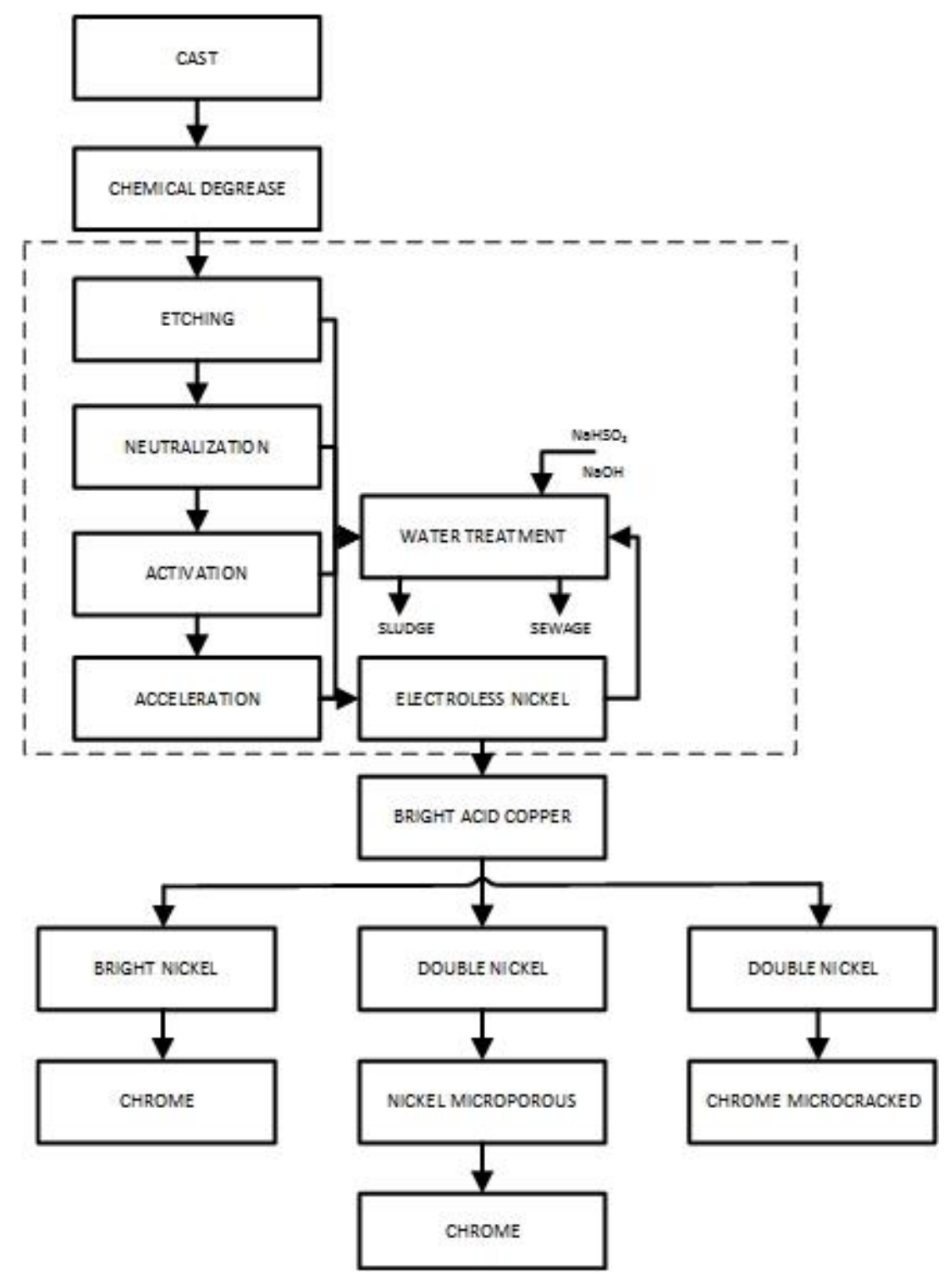

Fig. 1. System description. System boundaries analysed are marked with dash line 


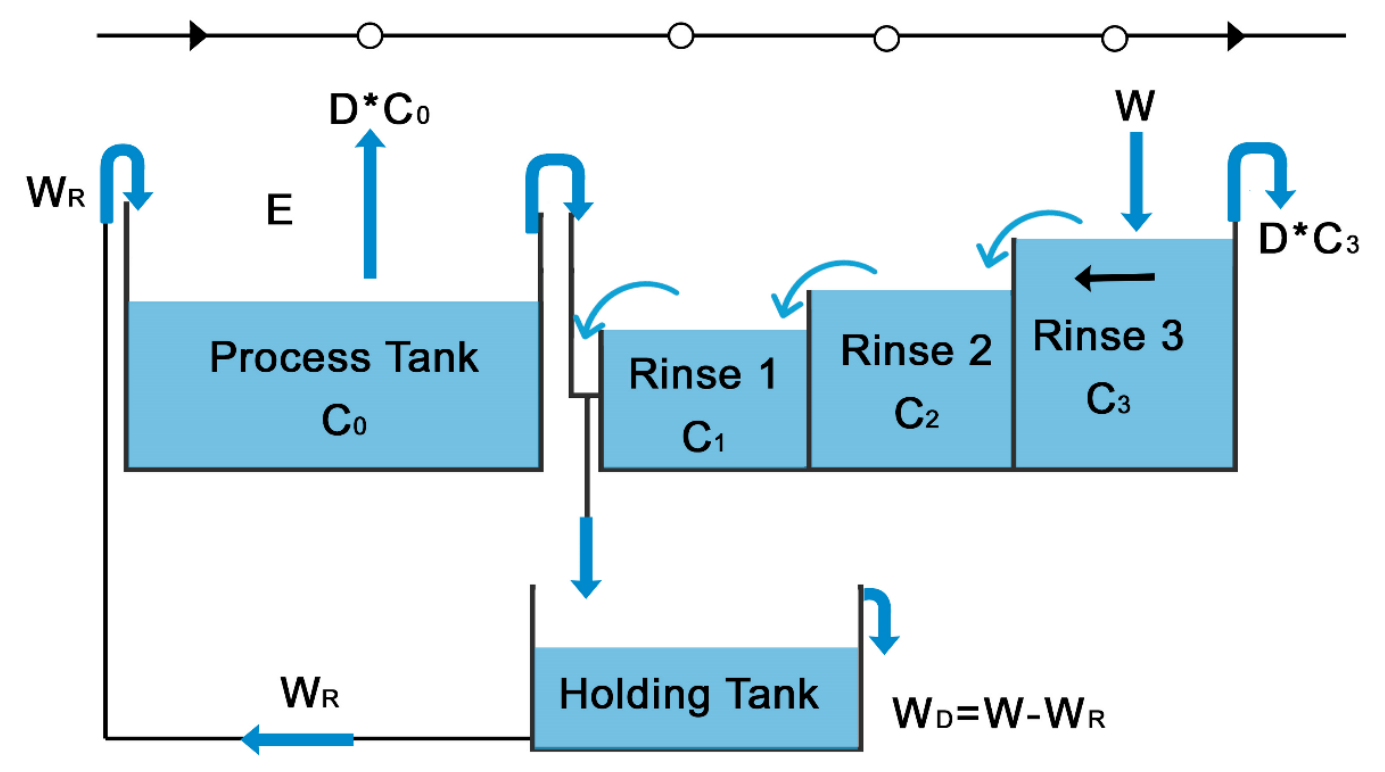

Fig. 2. Recovery of drag-out with triple counter flow rinse 


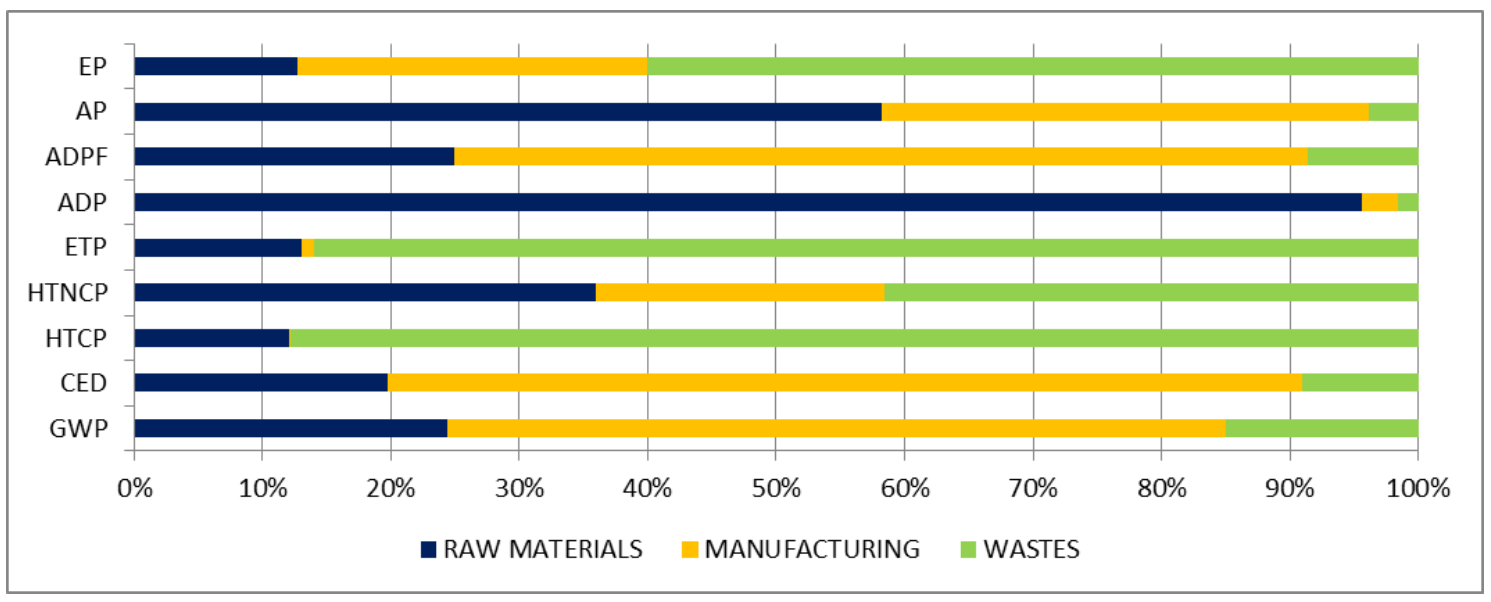

Fig. 3. Contribution of raw materials, manufacturing and wastes to total impacts 


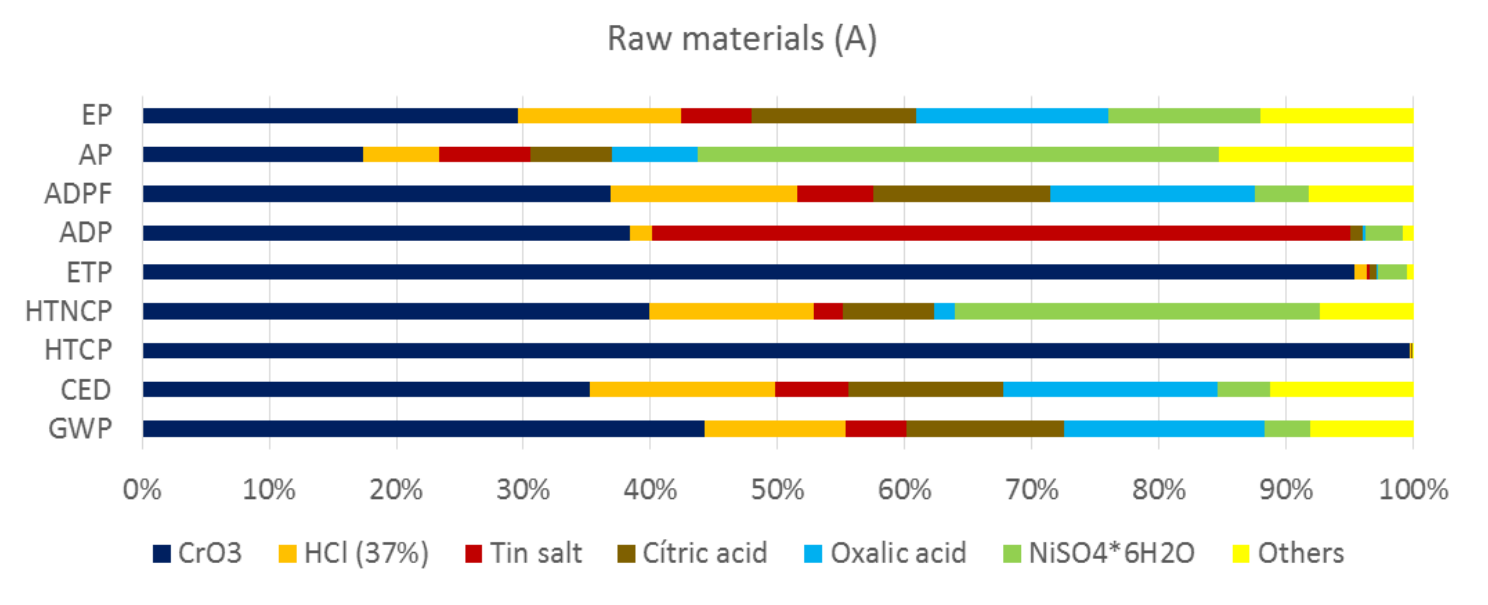

Raw Materials (B)

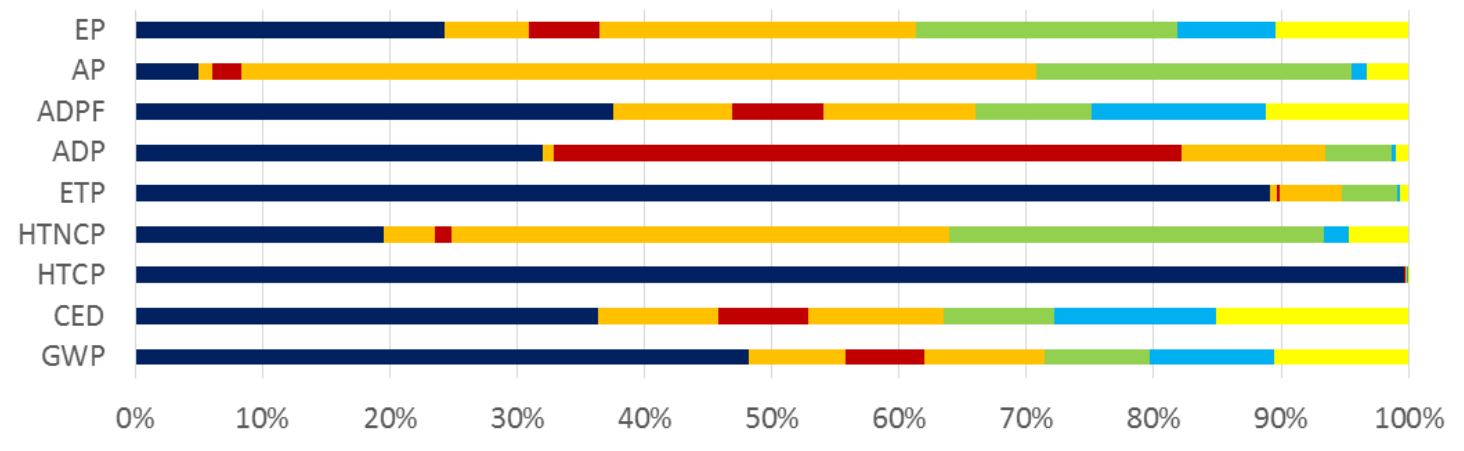

- $\mathrm{CrO} 3 \square \mathrm{HCl}(37 \%) \square$ Tin salt $\square$ Palladium (II) chloride $\square \mathrm{NiSO} 4 * 6 \mathrm{H} 2 \mathrm{O} \square \mathrm{NaPO} 2 \mathrm{H} 2{ }^{*} \mathrm{H} 2 \mathrm{O} \square$ Others

Fig. 4. Raw materials impacts. 


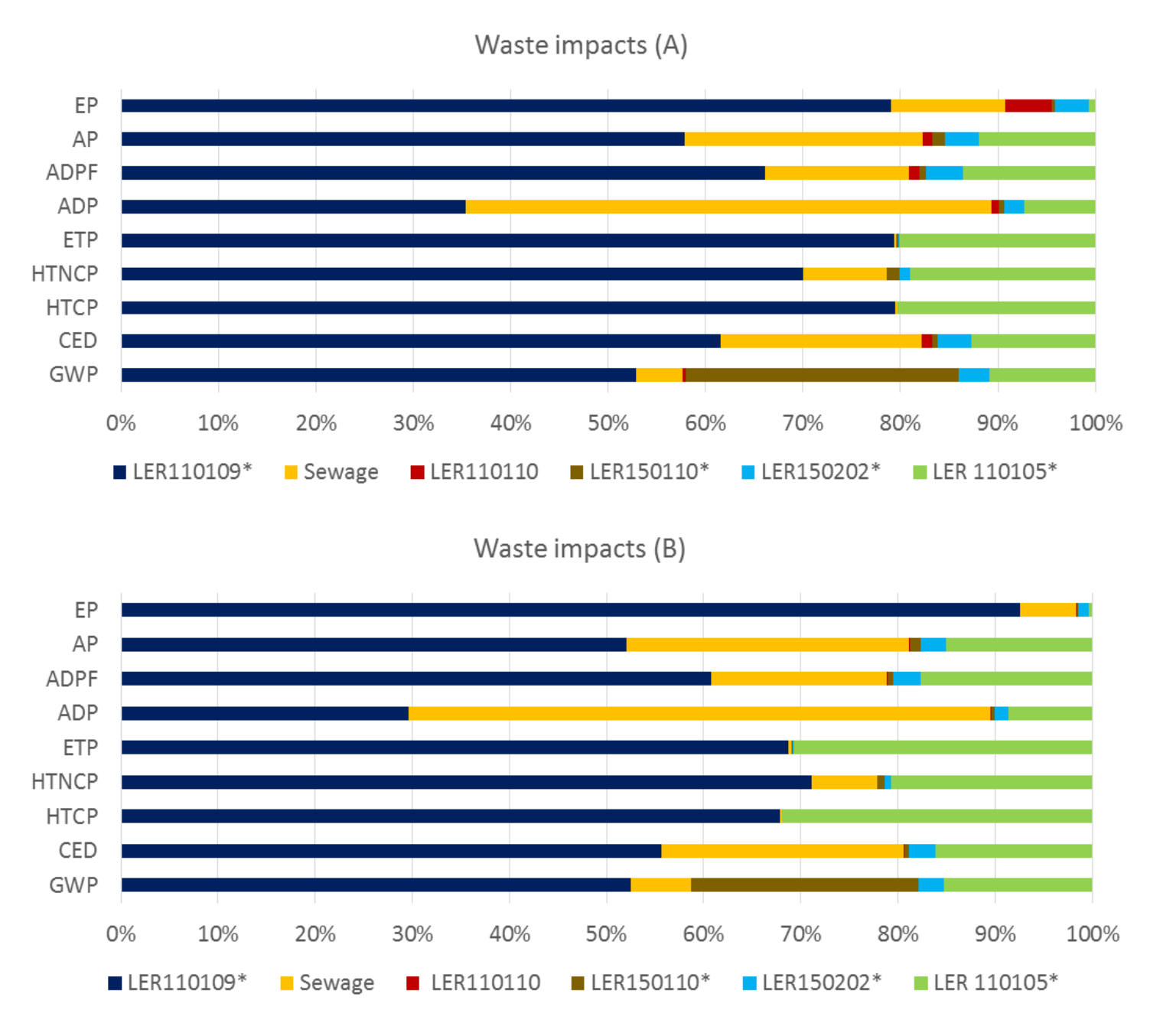

Fig. 5. Waste impacts (impacts of reagents procurement are not included) 
List of Tables

Table 1. List of inputs to treat $1 \mathrm{~m}^{2}$ of ABS

Table 2. Impact assessment for $1 \mathrm{~m}^{2}$ of surface treated

Table 3. Estimated air emissions

Table 4. Sensitivity analysis 


\begin{tabular}{|c|c|c|}
\hline Process & Inputs & Comments \\
\hline \multirow{4}{*}{ Etching } & $\mathrm{CrO}_{3}(\mathrm{C})$ & $\begin{array}{l}\text { Harscoet and Froelich [3], and Kowalski et al. } \\
\text { [23] }\end{array}$ \\
\hline & $\mathrm{H}_{2} \mathrm{SO}_{4}(\mathrm{C})$ & \\
\hline & Fumetrol 21 (A) & $\begin{array}{l}\text { Obtained from tetrafluoroethane and sulfuric } \\
\text { acid }\end{array}$ \\
\hline & Fumetrol 140 TR (B) & $\begin{array}{l}\text { Obtained from tetrafluoroethane, sulfuric acid } \\
\text { and fluorine }\end{array}$ \\
\hline \multirow{3}{*}{ Neutralization } & $\begin{array}{l}\text { Bis hydroxylammonium } \\
\text { sulfate (A) }\end{array}$ & $\begin{array}{l}\text { Obtained from hydroxylammine and sulfuric } \\
\text { acid }\end{array}$ \\
\hline & $\mathrm{HCl}(\mathrm{C})$ & \\
\hline & $\mathrm{SnCl}_{2}(\mathrm{~B})$ & $\begin{array}{l}\text { Obtained from the reaction of tin with } \\
\text { hydrochloric acid }\end{array}$ \\
\hline \multirow{6}{*}{ Activation } & $\begin{array}{l}\text { Tin } \quad \text { (II) } \quad \text { chloride } \\
\text { dihydrate }(A)\end{array}$ & $\begin{array}{l}\text { Obtained from the reaction of tin with } \\
\text { hydrochloric acid, water is then evaporated to } \\
\text { produce the crystals }\end{array}$ \\
\hline & Tin (II) chloride (B) & $\begin{array}{l}\text { Obtained from the reaction of tin with } \\
\text { hydrochloric acid }\end{array}$ \\
\hline & $\mathrm{HCl}(\mathrm{C})$ & \\
\hline & $\begin{array}{l}\text { Palladium (II) chloride } \\
\text { (C) }\end{array}$ & $\begin{array}{l}\text { Obtained from the reaction of palladium metal } \\
\text { with hydrochloric acid in the presence of } \\
\text { chlorine, water is used to produce the crystals }\end{array}$ \\
\hline & Sodium stannate (B) & $\begin{array}{l}\text { Obtained from a mixture of tin dioxide, sodium } \\
\text { hydroxide, and water }\end{array}$ \\
\hline & Resorcinol (A) & $\begin{array}{l}\text { Obtained from benzene disulfonic acid and } \\
\text { sodium hydroxide }\end{array}$ \\
\hline \multirow{6}{*}{ Acceleration } & Citric Acid (A) & \\
\hline & Oxalic Acid (A) & Obtained from nitric acid and starch \\
\hline & $\mathrm{H}_{2} \mathrm{SO}_{4}(\mathrm{~A})$ & \\
\hline & Fluoboric acid (B) & $\begin{array}{l}\text { Obtained from boron (II) oxide, water, and } \\
\text { hydrogen fluoride }\end{array}$ \\
\hline & Formic acid (B) & \\
\hline & Boric acid (B) & \\
\hline \multirow{5}{*}{$\begin{array}{l}\text { Electroless } \\
\text { Nickel }\end{array}$} & $\mathrm{NiSO}_{4} 6 \mathrm{H}_{2} \mathrm{O}(\mathrm{C})$ & \\
\hline & $\mathrm{NH}_{3}(\mathrm{~A})$ & \\
\hline & $\mathrm{NH}_{4} \mathrm{Cl}(\mathrm{C})$ & \\
\hline & $\mathrm{NaPO}_{2} \mathrm{H}_{2} \cdot \mathrm{H}_{2} \mathrm{O}(\mathrm{C})$ & $\begin{array}{l}\text { Obtained from an endothermic reaction with } \\
\text { phosphorus, sodium hydroxide, and water }\end{array}$ \\
\hline & $\mathrm{NH}_{4} \mathrm{OH}(\mathrm{B})$ & $\begin{array}{l}\text { Obtained from the reaction of ammonia with } \\
\text { water }\end{array}$ \\
\hline \multirow[t]{2}{*}{ General } & $\begin{array}{l}\text { Treated water (de- } \\
\text { ionised) }(C)\end{array}$ & \\
\hline & Sewage, to wastewater & Ecoinvent process: Sewage, to wastewater \\
\hline
\end{tabular}




\begin{tabular}{lll}
\hline Process & Inputs & Comments \\
\hline (C) & $\begin{array}{l}\text { treatment, class 3. Cr(VI) from reduction is } \\
\text { added to this process as water emission. }\end{array}$ \\
& \\
Diesel (A) & \\
Electricity, Spain (A) & \\
Electricity, Turkey (B) & \\
& $\mathrm{NaOH} \mathrm{(C)}$ & \\
\hline
\end{tabular}


Table 2. Impact assessment for $1 \mathrm{~m}^{2}$ of surface treated

\begin{tabular}{llrr}
\hline Impact category & Unit & IMPACT & STANDARD DEVIATION \\
\hline Climate change (GWP) & $\mathrm{kg} \mathrm{CO}{ }_{2}$ eq & 2.55 & 0.277 \\
Cumulative energy demand (CED) & $\mathrm{MJ}$ & 37.6 & 5.90 \\
Human toxicity, cancer (HTCP) & $\mathrm{CTUh}$ & $6.91 \cdot 10^{-05}$ & $8.76 \cdot 10^{-06}$ \\
Human toxicity, non-cancer (HTNCP) & $\mathrm{CTUh}$ & $5.73 \cdot 10^{-07}$ & $2.21 \cdot 10^{-07}$ \\
Eco-toxicity (ETP) & $\mathrm{CTUe}$ & 720 & 108 \\
Abiotic depletion (ADP) & $\mathrm{kg} \mathrm{Sb}$ eq & $5.26 \cdot 10^{-05}$ & $1.29 \cdot 10^{-05}$ \\
Abiotic depletion fossil fuels (ADPF) & $\mathrm{MJ}^{-05}$ & 28.4 & 4.06 \\
Acidification (AP) & $\mathrm{kg} \mathrm{SO}_{2}$ eq & $3.94 \cdot 10^{-02}$ & $2.08 \cdot 10^{-02}$ \\
Eutrophication (EP) & $\mathrm{kg} \mathrm{PO}_{4}$ eq & $1.09 \cdot 10^{-02}$ & $5.29 \cdot 10^{-03}$ \\
\hline
\end{tabular}


Table 3. Estimated air emissions

Contaminant

Value $\left(\mathrm{g} / \mathrm{m}^{2}\right)$

$\mathrm{Cr}(\mathrm{VI})$

$4.69 \cdot 10^{-08}$

$\mathrm{SO}_{3}$

$5.69 \cdot 10^{-08}$

$\mathrm{Cl}^{-}$

$5.16 \cdot 10^{-04}$ 
Table 4. Sensitivity analysis

\begin{tabular}{lrr}
\hline & $\begin{array}{c}\text { Transport } \\
\mathbf{5 0 0} \mathbf{~ k m}\end{array}$ & $\begin{array}{l}\text { Temperature } \\
\text { reduction in } \\
\text { baths -10\%C }\end{array}$ \\
\hline Climate change & $+1.1 \%$ & $-7.9 \%$ \\
Cumulative energy demand & $+0.3 \%$ & $-9.8 \%$ \\
Human toxicity, cancer & $0.0 \%$ & $0.0 \%$ \\
Human toxicity, non-cancer & $+0.5 \%$ & $-3.0 \%$ \\
Eco-toxicity & $+0.0 \%$ & $-0.1 \%$ \\
Abiotic depletion & $+0.2 \%$ & $-0.1 \%$ \\
Abiotic depletion (fossil fuels) & $+0.2 \%$ & $-9.1 \%$ \\
Acidification & $+0.6 \%$ & $-7.0 \%$ \\
Eutrophication & $+0.5 \%$ & $-4.6 \%$ \\
\hline
\end{tabular}

